\title{
Research on Fiscal Expenditure Structure and High-Quality Economic Development: An Empirical Study Based on Panel Data from Chinese Provinces from 2007 to 2017
}

\author{
Yaying Liu \\ School of Economics, Jinan University, Guangzhou, China \\ Email: 15622113626@163.com
}

How to cite this paper: Liu, Y. Y. (2020). Research on Fiscal Expenditure Structure and High-Quality Economic Development: An Empirical Study Based on Panel Data from Chinese Provinces from 2007 to 2017. American Journal of Industrial and Business Management, 10, 232-249.

https://doi.org/10.4236/ajibm.2020.102015

Received: January 7, 2020

Accepted: February 8, 2020

Published: February 11, 2020

Copyright $\odot 2020$ by author(s) and Scientific Research Publishing Inc. This work is licensed under the Creative Commons Attribution International License (CC BY 4.0).

http://creativecommons.org/licenses/by/4.0/

(c) (i) Open Access

\begin{abstract}
This paper quantitatively measures the quality of economic development in 30 provinces in China from 2007 to 2017 by constructing a quality of economic development comprehensive evaluation index system. Based on this, a systematic GMM empirical analysis model is used to examine the effect of fiscal expenditure structure on the quality of economic development. The research results show that, at the macro level, all types of fiscal expenditures have a positive effect on the quality of economic development, and they are ranked from large to small in terms of environmental protection expenditures, social security and employment expenditures, science, education, cultural and health expenditures, economic construction expenditures, general public service expenditure. At the meso level, science, education, cultural and health expenditures, social security and employment expenditures, and economic construction expenditures in the eastern, central, and western regions all have a positive impact on the quality of economic development. There is obvious regional heterogeneity in the impact of general public service expenditure and environmental protection expenditure on the quality of economic development. Suggestions are put forward to optimize the structure of China's fiscal expenditure to enable high-quality economic development.
\end{abstract}

\section{Keywords}

Fiscal Expenditure Structure, High-Quality Economic Development, Regional Heterogeneity, SYS-GMM

\section{Introduction}

The different stages of economic and social development have different re- 
quirements for government functions. The difference in the scope of government activities and policy tendencies directly affects the structure of fiscal expenditure. Since the reform and opening up, China's economic management system has undergone a fundamental change from "planning" to "marketing", government functions have changed from advocating "construction finance" to "public finance" to "people's livelihood finance", and the economy has been adjusted from a high-speed development stage to a gear-up shift phase. All of these are accompanied by the changing structure of fiscal expenditure. Since the report of the 19th National Congress of the Communist Party of China clearly pointed out that China's economy has entered a stage of high-quality development, the National Economic Work Conference, the Government Work Report, and the National Two Conferences, etc. have repeatedly mentioned "high-quality economic development", conveying the continuous implementation of the spirit of the Nineteenth National Congress and determination to promote high-quality economic development. Therefore, China's fiscal expenditure structure should also be optimized and adjusted accordingly, to better play the role of fiscal expenditure and empower high-quality economic development.

Most of the existing literature is studying the relationship between fiscal expenditure structure and economic growth rate (Aschauer, 1989; Devarajan et al., 1993; Barro, 1990; Guo et al., 2003; Sun \& Zhang, 2004; Zeng \& Zhao, 2005; Wang, 2009). Different scholars have different models, research methods, and calibers, so their conclusions are also different. However, research on the structure of fiscal expenditure based on economic growth rate seems to weaken the basic function of fiscal expenditure as one of the important means for the government to solve market failures, and many areas related to the quality of economic development such as education and medical care, employment, social security, and the ecological environment are precisely the areas where the market fails the most frequently. In fact, the structural arrangement of fiscal expenditure must be subject to the inherent requirements of the three fiscal functions: resource allocation, income distribution, and stable economy. In this sense, only studying the relationship between the structure of fiscal expenditure and economic growth underestimates the effect of the structural arrangement of fiscal expenditure on economic and social development. Therefore, some studies have expanded the scope of fiscal expenditure structure analysis, combining fiscal expenditure structure with areas such as income distribution, social equity, retirement, health, and education that the most frequent market failures and affect the quality of economic development. For example, Chengkui Liu and Chaocai Wang (2008) measured social equity based on the per capita income gap between urban and rural households, and studied the impact of fiscal expenditure structure on social equity. Xixiang Wei and Fan Li (2012) Construct a National Happiness Index $(\mathrm{GNH})$ accounting system that includes five indexes: gross domestic product index, social health index, social welfare index, social civilization index, and ecological environment index. Use the GNH index to make re- 
gression analysis on economic construction costs, social culture and education costs, and national defense expenditures, and study the impact of fiscal expenditure structural benefits on the national happiness index. Chengliang Yan (2017) deduced the effects of delayed retirement and adjustment of fiscal expenditure structure on pensions replacement rate using an intertemporal iteration (OLG) model. $\mathrm{Na}$ Li et al. (2018) constructed comprehensive socio-economic development indicators including per capita GDP, energy efficiency and human development index HDI (comprehensive indicators of education, people's health and living standards), studied the socio-economic effects of fiscal expenditure structure, and highlighted the evaluation of economic quality.

Compared with the existing literature, the contributions of this paper are: First, on the premise of distinguishing the quality of economic growth and the quality of economic development, the definition of high-quality economic development is defined, and on the basis of this, the comprehensive evaluation index system for the quality of economic development is reconstructed; second, there are few studies that combine the structure of fiscal expenditure with the quality of economic development. Rather than establishing models to analyze the individual effects of economic quality on the basis of different types of fiscal expenditure, this paper takes the quality of economic development as the explanatory variable and multiple different types of fiscal expenditure as the main explanatory variables. It establishes a multiple regression model that can assess the relative importance of different types of fiscal expenditure to economic quality and determine the comprehensive effect; third, in the regional regression, this paper adopts the "full interaction term" method, which not only preserves the sample information to make the regression results more accurate, but also enables to compare between groups. This paper will construct a dynamic panel data model and use SYS-GMM research methods to empirically examine the relationship between fiscal expenditure structure and the quality of economic development at the macro level (national) level and the middle level (east region, central region, and western region), provide corresponding policy recommendations to optimize the structure of China's fiscal expenditure and enable high-quality economic development.

\section{Construction and Measurement of Comprehensive Evaluation Index System for Economic Development Quality}

\subsection{The Connotation of High-Quality Economic Development}

In the late 1990s, China began to focus on the study of the quality of economic growth. The content of the quality of economic growth includes growth efficiency, economic structure, growth stability (Xiao \& Li, 1998; Zhong, 2001; Zhao et al., 2006), as well as the higher per capita output, fairer welfare distribution, lower ecological and environmental costs (Wei \& Ren, 2012). The quality of economic development began to be studied after the 19th National Congress. At 
present, there is no authoritative definition or scientific distinction between these two concepts. They are all relative growth numbers. The quality of economic growth is the vertical deepening of economic growth, and the embodiment of the inherent nature and laws of economic growth. The quality of economic growth should be embedded in the quality of economic development (Ren, 2018), that is, the quality of economic development is a broader concept, and its extension is richer than the quality of economic growth, which has become the mainstream view of the academic community. High-quality economic development is the coordinated development of social, cultural, ecological, and human modernization on the basis of achieving qualitative economic growth, emphasizing the combination of economic, social, and ecological benefits (Sun, 2018; Ren \& Li, 2018).

Therefore, this paper thinks that high-quality economic development is based on the qualitative growth of the economy that has achieved power conversion, efficiency improvement, stability enhancement, and structural optimization, a process of simultaneous development, continuous progress, and advancement of people's livelihood, human development, ecological environment, etc. social and ecological areas in a country or region.

\subsection{Construction of Comprehensive Evaluation Index System for Economic Development Quality}

This paper refers to the construction of a comprehensive evaluation index system for the quality of economic growth by Xiaojing Chao (2009) and Baoping Ren (2018), focusing on the "conversion of growth momentum" since the 19th National Congress, so a special dimension index of "growth momentum" has been added to highlight the importance of basic indicators for technological innovation. The transformation of "growth drivers" is the premise and basis for achieving "efficiency change" and "transformation of development mode". The promotion of "people's livelihood" and the realization of "green sustainable development" are related to people's longing for a better life. They are all due to high-quality economic development. Taking into account the availability of data and the hierarchy of the evaluation system, a comprehensive evaluation index system for the quality of economic development has been restructured. The specific composition is shown in Table 1.

\subsection{Measurement of the Quality of Economic Development}

This paper selects the provincial panel data of China from 2007 to 2017. The index data are mainly from China Statistical Yearbook, China Energy Statistical Yearbook, China Industrial Economic Statistical Yearbook, and China Population and Employment Statistical Yearbook.

Because the basic index has different attributes and dimensions, this paper first uses the reciprocal method to homogenize the indicators, and then uses the mean standardization method for dimensionless processing. In terms of index weighting, this paper uses the entropy method (Wei \& Li, 2018). The measurement results are shown in Table 2. 
Table 1. Comprehensive evaluation index system for the quality of economic development.

\begin{tabular}{|c|c|c|c|c|}
\hline Index dimension & Secondary index & Basic index & Index description & Index attribute \\
\hline \multirow{5}{*}{$\begin{array}{l}\text { Growth } \\
\text { momentum }\end{array}$} & \multirow{2}{*}{$\begin{array}{l}\text { Innovation-Driven } \\
\text { Level }\end{array}$} & R \& D level & $\begin{array}{l}\text { Three domestic patent application } \\
\text { authorizations/R \& D funding }\end{array}$ & + \\
\hline & & $\mathrm{R} \& \mathrm{D}$ investment intensity & $\mathrm{R} \& \mathrm{D}$ funding/GDP & + \\
\hline & \multirow{3}{*}{ Productivity } & Capital productivity & GDP/total investment in fixed assets & + \\
\hline & & Labor productivity & Real GDP/employees of the whole society & + \\
\hline & & Energy productivity & Real GDP/total energy consumption & + \\
\hline \multirow{6}{*}{ Growth structure } & Industrial structure & $\begin{array}{c}\text { Proportion of non-agricultural } \\
\text { industries }\end{array}$ & $\begin{array}{l}\text { Added value of secondary and tertiary } \\
\text { industries/GDP }\end{array}$ & + \\
\hline & Investment and & Investment rate & Capital formation rate & + \\
\hline & structure & Consumption rate & Final consumption rate & + \\
\hline & $\begin{array}{l}\text { Income distribution } \\
\text { structure }\end{array}$ & Urban-rural income ratio & $\begin{array}{l}\text { Per capita disposable income of urban } \\
\text { residents/Per capita disposable income } \\
\text { of rural residents }\end{array}$ & + \\
\hline & Balance of payments & Foreign trade dependence & Total imports and exports/GDP & + \\
\hline & structure & Foreign dependency & Total foreign investment/GDP & + \\
\hline \multirow{4}{*}{ Growth stability } & Output fluctuation & Economic volatility & GDP growth rate & - \\
\hline & Price fluctuation & Inflation rate & $\mathrm{CPI}_{\mathrm{t}}-\mathrm{CPI}_{\mathrm{t}-1} / \mathrm{CPI}_{\mathrm{t}-1}$ & - \\
\hline & $\begin{array}{l}\text { Employment } \\
\text { fluctuations }\end{array}$ & unemployment rate & Urban registered unemployment rate & - \\
\hline & Income level & $\begin{array}{l}\text { Per capita disposable } \\
\text { income of residents }\end{array}$ & - & + \\
\hline \multirow[t]{2}{*}{ Well-being } & Educational benefits & Years of education per capita & $\begin{array}{c}\text { (Primary education level population }{ }^{\star} 6+ \\
\text { Junior high school education level } \\
\text { population }{ }^{\star} 9+\text { High school education } \\
\text { level population }{ }^{\star} 12+\text { College level } \\
\text { education level or above }{ }^{\star} 16 \text { )/Sample } \\
\text { total population over the age of six }\end{array}$ & + \\
\hline & Social Security & $\begin{array}{l}\text { Social security expenditure } \\
\text { per capita }\end{array}$ & $\begin{array}{l}\text { Real Social Security and Employment } \\
\text { Expenditure/Total Population }\end{array}$ & + \\
\hline \multirow{4}{*}{$\begin{array}{c}\text { Green sustainable } \\
\text { development }\end{array}$} & $\begin{array}{l}\text { Environmental } \\
\text { pollution }\end{array}$ & $\begin{array}{l}\text { Total emissions of major } \\
\text { pollutants in exhaust gas }\end{array}$ & $\begin{array}{c}\text { Total emissions of major pollutants in } \\
\text { exhaust gas/real GDP }\end{array}$ & - \\
\hline & & Total wastewater discharge & Total wastewater discharge/real GDP & - \\
\hline & \multirow{2}{*}{$\begin{array}{l}\text { Environmental } \\
\text { protection }\end{array}$} & Forest cover rate & - & + \\
\hline & & $\begin{array}{l}\text { Environmental protection } \\
\text { expenditure per capita }\end{array}$ & $\begin{array}{l}\text { Actual environmental protection } \\
\text { expenditure/total population }\end{array}$ & + \\
\hline
\end{tabular}

Note: In the multi-indicator comprehensive evaluation, the positive index (indicated by " + " in the index attribute column in Table 1) indicates that when the index value is larger, the quality of economic development is better; the reverse index (indicated by "-" in the index attribute column in Table 1) indicate that the greater the index value, the worse the quality of economic development.

In the horizontal comparison of areas, the top 10 provinces in the comprehensive index of the quality of economic development, the top 9 are located in eastern China; the middle 10 ranks, 5 provinces belong to the central area, and 4 provinces belong to The western area; of the bottom 10 provinces, only Hebei 
Table 2. China's provincial economic development quality comprehensive index and ranking in 2007-2017.

\begin{tabular}{|c|c|c|c|c|c|c|c|c|c|}
\hline Province & 2007 & 2009 & 2011 & 2013 & 2015 & 2017 & Mean & Rank & Area \\
\hline Beijing & 0.39964 & 0.45264 & 0.51320 & 0.56529 & 0.63254 & 0.69341 & 0.54036 & 1 & East \\
\hline Shanghai & 0.38258 & 0.40275 & 0.45658 & 0.46086 & 0.49490 & 0.59728 & 0.46493 & 2 & East \\
\hline Guangdong & 0.33637 & 0.35262 & 0.37575 & 0.39429 & 0.40207 & 0.43741 & 0.38084 & 3 & East \\
\hline Zhejiang & 0.26003 & 0.30594 & 0.33236 & 0.36440 & 0.38700 & 0.41732 & 0.34393 & 4 & East \\
\hline Tianjin & 0.27776 & 0.28660 & 0.30956 & 0.34081 & 0.38165 & 0.44082 & 0.33689 & 5 & East \\
\hline Hainan & 0.29013 & 0.30837 & 0.28421 & 0.29866 & 0.33441 & 0.35978 & 0.30681 & 6 & East \\
\hline Jiangsu & 0.24133 & 0.26327 & 0.29285 & 0.31338 & 0.33552 & 0.35265 & 0.29866 & 7 & East \\
\hline Liaoning & 0.21119 & 0.23988 & 0.25968 & 0.30288 & 0.33081 & 0.39759 & 0.29043 & 8 & East \\
\hline Fujian & 0.22838 & 0.26104 & 0.27577 & 0.29513 & 0.31966 & 0.33421 & 0.28469 & 9 & East \\
\hline Chongqing & 0.14159 & 0.19829 & 0.23848 & 0.27670 & 0.30431 & 0.32926 & 0.24775 & 10 & West \\
\hline Heilongjiang & 0.17891 & 0.20664 & 0.22230 & 0.25829 & 0.29380 & 0.32483 & 0.24347 & 11 & Central \\
\hline Jiangxi & 0.18184 & 0.21029 & 0.22609 & 0.25404 & 0.27418 & 0.30060 & 0.23980 & 12 & Central \\
\hline Jilin & 0.17609 & 0.20620 & 0.22439 & 0.25236 & 0.27308 & 0.29510 & 0.23742 & 13 & Central \\
\hline Qinghai & 0.14440 & 0.18655 & 0.21801 & 0.25421 & 0.30719 & 0.31602 & 0.23631 & 14 & West \\
\hline Inner Mongolia & 0.14346 & 0.19271 & 0.21851 & 0.25605 & 0.29410 & 0.32057 & 0.23600 & 15 & West \\
\hline Shaanxi & 0.14699 & 0.19511 & 0.21128 & 0.24884 & 0.28652 & 0.29877 & 0.23044 & 16 & West \\
\hline Shandong & 0.17098 & 0.19571 & 0.21688 & 0.24880 & 0.26222 & 0.28469 & 0.22915 & 17 & East \\
\hline Guangxi & 0.15236 & 0.20179 & 0.20967 & 0.23703 & 0.27312 & 0.30519 & 0.22676 & 18 & West \\
\hline Hubei & 0.13977 & 0.18327 & 0.19571 & 0.23523 & 0.28088 & 0.30566 & 0.22276 & 19 & Central \\
\hline Hunan & 0.15078 & 0.19078 & 0.19533 & 0.22705 & 0.25524 & 0.29152 & 0.21664 & 20 & Central \\
\hline Yunnan & 0.13218 & 0.17749 & 0.19440 & 0.22089 & 0.25266 & 0.28319 & 0.21012 & 21 & West \\
\hline Shanxi & 0.16127 & 0.17989 & 0.18536 & 0.22343 & 0.24807 & 0.27483 & 0.20994 & 22 & Central \\
\hline Anhui & 0.12291 & 0.16358 & 0.18922 & 0.23067 & 0.25850 & 0.27736 & 0.20552 & 23 & Central \\
\hline Sichuan & 0.12804 & 0.16777 & 0.18879 & 0.22228 & 0.24520 & 0.27147 & 0.20431 & 24 & West \\
\hline Henan & 0.13433 & 0.16865 & 0.17914 & 0.21606 & 0.24326 & 0.26364 & 0.20000 & 25 & Central \\
\hline Xinjiang & 0.12794 & 0.16633 & 0.17746 & 0.19810 & 0.24312 & 0.27021 & 0.19667 & 26 & West \\
\hline Gansu & 0.12778 & 0.15845 & 0.17645 & 0.21031 & 0.24215 & 0.25871 & 0.19462 & 27 & West \\
\hline Ningxia & 0.11851 & 0.15586 & 0.16337 & 0.20141 & 0.25629 & 0.29232 & 0.19459 & 28 & West \\
\hline Hebei & 0.13352 & 0.16311 & 0.17295 & 0.20308 & 0.23715 & 0.25638 & 0.19298 & 29 & East \\
\hline Guizhou & 0.10968 & 0.15999 & 0.16120 & 0.19812 & 0.22068 & 0.24002 & 0.18076 & 30 & West \\
\hline
\end{tabular}

Note: The eastern, central and western areas are divided into three major areas according to the China Statistical Yearbook.

Province is in the eastern area, 3 provinces are in the central area, and 6 provinces are in the western area. This shows that the quality of economic development in the eastern area of China is higher than that in the central area, and the central area is higher than the western area. Most provinces in the eastern area rely on the advantages of open coastal areas and preferential policies to rank first 
in the quality of economic development. In 2017, Beijing (0.69341), the highest comprehensive quality index of economic development, was 2.9 times higher than Guizhou (0.240081), the lowest comprehensive quality index of economic development, further indicating that there are large regional differences in the quality of economic development in China.

\section{Theoretical Analysis and Research Hypothesis}

The structure of fiscal expenditures reflects the flow and distribution of government funds, and reflects the government's focus on regulating resource allocation, correcting market failures, and guiding social and economic development. This paper classifies fiscal expenditure into five categories: general public service expenditure, economic construction expenditure, science, education, cultural and health expenditure, social security and employment expenditure, and environmental protection expenditure, theoretical analyzes the impact of different types of fiscal expenditure on the quality of economic development, and then put forward the research hypothesis.

General public service expenditure is conducive to creating a good operating environment for social and economic development, but the effectiveness of general public service expenditure is largely affected by factors such as the level of regional economic development, population quality, rent-seeking and corruption; economic construction expenditure provides a good economic environment and sufficient and effective economic infrastructure for the rapid expansion of the private sector. According to Richard Abel Musgrave and Walt Whitman Rostow's theory of stages of economic growth, based on the basic national conditions in China's primary stage, economic construction expenditure is still of great significance for the high-quality development of China's economy; western economic theory has always emphasized the importance of fiscal expenditures in terms of human capital and technological innovation to economic development in the process of updating and development, such as Karl Heinrich Marx economic theory, Joseph Alois Schumpeter innovation theory, Robert Solow's neo-classical economic growth theory all believe that technological innovation is the real source of economic development; Theodore William Schultz and Gary S. Becker's Modern human capital theory, Paul Romer's knowledge spillover model, Lucas' human capital spillover model consider human capital as an important factor affecting economic development. Human capital and Scientific and technological innovation is the first driving force for development. Fiscal expenditures for science, education, culture, and health support are conducive to improving the effective supply of labor and the production efficiency of production factors such as labor, knowledge, technology, and management; the government through the "automatic stabilizer" function of social security and employment expenditure and moderate intervention, reduce output fluctuations, employment fluctuations to enhance the stability of economic growth, adjust the distribution relationship so that people share development results, and it is of 
great significance to improve the quality of economic development; environmental resources are public goods, with unclear property rights, non-competitive and non-exclusive attributes. It is difficult to implement the principle of "who pollutes who governs and who develops who protects." Users or polluters have serious adverse selection and moral hazard. In the end, environmental resources will be gradually polluted or even depleted, resulting in a "public tragedy" of environmental resources. The government improves environmental quality by increasing environmental protection expenditures, comprehensively using administrative management, subsidies or taxation charges, publicity and education, engineering projects and other means and methods. Good environmental quality is the due meaning of sustainable development and high-quality development of the economy and society.

In addition, due to natural, historical, and development strategies, China's area development is imbalanced and inadequate, and the influence of area fiscal expenditure structure on the quality of economic development will be different. According to George Joseph Stigler, public goods and services provided by local governments should meet the diverse public needs of local residents and maximize the benefits of public spending. Different levels of economic and social development in different areas in China, and different area public needs and development requirements, determine the different focus of government functions, and greatly affect the structure of fiscal expenditure.

Based on the above analysis, this paper proposes the following research hypotheses that can be verified.

Hypothesis 1: With other conditions unchanged, the quality of economic development is related to the general public service expenditure.

Hypothesis 2: With other conditions unchanged, the quality of economic development is positively related to economic construction expenditure.

Hypothesis 3: With other conditions unchanged, the quality of economic development is positively related to expenditure on science, education, culture, and health.

Hypothesis 4: With other conditions unchanged, the quality of economic development is positively related to social security and employment expenditure.

Hypothesis 5: With other conditions unchanged, the quality of economic development is positively related to environmental protection expenditure.

Hypothesis 6: There is regional heterogeneity in the impact of fiscal expenditure structure on the quality of economic development.

\section{Model Construction and Data Source}

\subsection{Model Construction}

It is generally believed that the quality of economic development is dependent on road strength, that is, the quality of economic development is a long-term continuous accumulation and continuous self-reinforcing process. Therefore, the lag period of the quality of economic development is also introduced as one 
of the explanatory variables in the model to establish a dynamic regression model, which is used to study the relationship between general public service expenditure $(P S)$, science, education, culture and health expenditure $(S E C H)$, social security expenditure $(S S)$, economic construction expenditure $(E P)$, and environmental protection expenditure $(E C)$ and the quality of economic development $(Q E G)$. The basic model is as follows:

$$
\begin{aligned}
Q E G_{i t}= & C_{0}+\alpha_{0} Q E G_{i t-1}+\alpha_{1} P S_{i t}+\alpha_{2} S E C H_{i t}+\alpha_{3} S S_{i t} \\
& +\alpha_{4} E P_{i t}+\alpha_{5} E C_{i t}+\alpha_{k} \sum X_{i t}+\varepsilon
\end{aligned}
$$

where $i$ is the cross-sectional variable (provincial domain), $t$ is the time variable (year), $X$ is each control variable; $\varepsilon$ is the error term.

\subsection{Variables and Data Description}

According to the existing literature research, the following control variables are selected: 1) Fiscal Expenditure Scale (EXP), which is reflected by the ratio of general fiscal budget expenditure to GDP of each province, and is used to control the impact of fiscal expenditure scale on the quality of economic development (Lin \& Sun, 2017; Guo, 2018). 2) Economic development level (PGDP), expressed as GDP per capita (Lin \& Sun, 2017; Zhan \& Wang, 2017). The better the economic development of an area, the higher the level of economic benefits, and Correspondingly the higher the quality of the economic development, so it is added as a control variable. 3) The degree of economic openness (OPEN), measured by the degree of dependence on foreign trade, that is, the ratio of total imports and exports to GDP (Lin \& Sun, 2017; Guo, 2018; Zhan \& Wang, 2017). The higher the degree of opening to the outside world, the more active social and economic activities, and the faster the update speed of knowledge, technology, and management, which will affect the improvement of the quality of economic development.

This paper selects panel data from 30 provinces in China from 2007 to 2017. The data of the explanatory variable "quality of economic development" comes from the above calculation results. The data of various fiscal expenditures are from the National Bureau of Statistics Annual Data by province "Finance-Local Fiscal Expenditure". The data of fiscal expenditure scale, GDP and total import and export data are respectively derived from the annual data of the national database "Finance", "National Accounts" and "Foreign Economic and Trade". Taking into account the availability of data and the research needs of this paper, this paper divides and calculates financial expenditure according to expenditure function after the 2007 fiscal revenue and expenditure classification reform. At the same time, in order to simplify the expenditure items, combine scientific and technological expenditures, education expenditures, cultural and sports expenditures, media expenditures, and health care expenditures these similar characteristics fiscal expenditures as scientific, educational, cultural, and health expenditures, and urban and rural community affairs expenditures, agriculture, forestry, and water affairs expenditures, and transportation expenditures are classified as 
economic construction expenditures. General public service expenditures, social security and employment expenditures, and environmental protection expenditures are treated as separate items. Variables and data description are shown in Table 3.

\section{Empirical Analysis}

\subsection{Impact of Macro-Level Fiscal Expenditure Structure on High-Quality Economic Development}

\subsubsection{Estimation Method and Result Analysis}

In order to solve the problem that lagging explanatory variables are introduced as explanatory variables, there may be interactions between various types of fiscal expenditure and the quality of economic development, which will cause "endogenous variable deviations" to get inconsistent estimates. This paper uses the System Generalized Method of Moments (SYS-GMM) to perform regression estimation on the above models. The regression results are as follows.

According to the regression results of model (1) to model (4) (as shown in Table 4), it can be seen that the lagging explanatory variable "QEG (-1)" has a significant coefficient at the $1 \%$ level and the sign remains unchanged, indicating that there is indeed a continuous accumulation and self-reinforcing development process in the quality of economic development. In all regressions, the $\mathrm{P}$ value of $A R(1)$ is close to 0 , but the P value of $A R(2)$ is greater than 0.1 , which means that the null hypothesis "no autocorrelation in the disturbance term" is accepted. At the same time, the results of the heteroscedasticity robust Hansen test reject the null hypothesis, indicating that the instrumental variables are not overrecognized. In addition, there is no multicollinearity among the variables. Therefore, our model settings are reasonable and the SYS-GMM can be used.

The empirical results show that the coefficient estimates of various types of fiscal expenditure are significantly positive, indicating that all types of fiscal expenditure have a positive role in promoting the quality of economic development. With other variables remaining the same, for every 1 unit increase in environmental protection expenditure, the quality of economic development improves by 0.456 units, and Hypothesis 5 is proved. Environmental protection expenditure has the strongest promotion effect on the quality of economic development. Good environmental quality is the proper meaning of the quality of economic development. For every 1 unit increase in social security and employment expenditure, the quality of economic development is improved by 0.296 units, and Hypothesis 4 is proved. Social security and employment expenditure are one of the important means to regulate distribution relationship and promote social equity. At this stage, achieving development results sharing and human development is the foothold and ultimate goal of high-quality economic development. For every 1 unit increase in expenditure on science, education, culture, and health, the quality of economic development improves by 0.211 units, and Hypothesis 3 is proved. The expenditure of science, education, culture, and health on the quality of economic development is not as strong as that 
Table 3. Variable names, calculation methods, and descriptive statistics.

\begin{tabular}{|c|c|c|c|c|c|c|c|}
\hline Variable type & Variable name & Calculation method & Obs. & Mean & Std. & Min & Max \\
\hline Explained variable & $\begin{array}{l}\text { Quality of economic } \\
\text { development }\end{array}$ & Based on the above calculation results & 330 & 0.26 & 0.095 & 0.11 & 0.693 \\
\hline \multirow{5}{*}{$\begin{array}{l}\text { Core explanatory } \\
\text { variables }\end{array}$} & $\begin{array}{l}\text { General public service } \\
\text { expenditure }\end{array}$ & $\begin{array}{l}\text { General Public Service Expenditure/General Fiscal } \\
\text { Budget Expenditure }\end{array}$ & 330 & 0.111 & 0.034 & 0.042 & 0.205 \\
\hline & $\begin{array}{l}\text { Science, Education, } \\
\text { Culture and Health } \\
\text { expenditure }\end{array}$ & $\begin{array}{l}\text { (Science and Technology Expenditure + Education } \\
\text { Expenditure + Cultural Sports and Media } \\
\text { Expenditure + Medical Expenditure)/General } \\
\text { Fiscal Budget Expenditure }\end{array}$ & 330 & 0.274 & 0.036 & 0.183 & 0.347 \\
\hline & $\begin{array}{l}\text { Social security and } \\
\text { employment } \\
\text { expenditure }\end{array}$ & $\begin{array}{l}\text { Social Security and Employment } \\
\text { Expenditure/General Fiscal Budget Expenditure }\end{array}$ & 330 & 0.128 & 0.032 & 0.058 & 0.275 \\
\hline & $\begin{array}{l}\text { Environmental } \\
\text { protection expenditure }\end{array}$ & $\begin{array}{l}\text { Environmental Protection Expenditure/General } \\
\text { Fiscal Budget Expenditure }\end{array}$ & 330 & 0.03 & 0.011 & 0.008 & 0.067 \\
\hline & $\begin{array}{l}\text { Economic construction } \\
\text { expenditure }\end{array}$ & $\begin{array}{l}\text { (Urban and rural community affairs expenditure + } \\
\text { agriculture, forestry and water affairs expenditure } \\
+ \text { transportation expenditure)/General Fiscal } \\
\text { Budget Expenditure }\end{array}$ & 330 & 0.262 & 0.047 & 0.149 & 0.384 \\
\hline \multirow{3}{*}{ Control variable } & Scale of fiscal expenditure & General Fiscal Budget Expenditure /GDP & 330 & 0.228 & 0.097 & 0.087 & 0.627 \\
\hline & GDP per capita & Real GDP per capita in 2007 & 330 & 3.673 & 2.054 & 0.794 & 11.077 \\
\hline & Level of opening up & Total imports and exports/GDP & 330 & 0.305 & 0.366 & 0.017 & 1.784 \\
\hline
\end{tabular}

Table 4. Results of the gradual regression of the quality of economic development on the structure of fiscal expenditure.

\begin{tabular}{|c|c|c|c|c|c|c|}
\hline Model & (1) & (2) & (3) & (4) & (5) & (6) \\
\hline Estimation method & SYS-GMM & SYS-GMM & SYS-GMM & SYS-GMM & $\mathrm{FE}$ & OLS \\
\hline QEG $(-1)$ & $\begin{array}{l}1.025^{\star * *} \\
(0.015)\end{array}$ & $\begin{array}{l}1.005^{\star * *} \\
(0.024)\end{array}$ & $\begin{array}{c}0.935^{\star * *} \\
(0.025)\end{array}$ & $\begin{array}{c}0.767^{\star * *} \\
(0.042)\end{array}$ & $\begin{array}{c}0.711^{\star * *} \\
(0.031)\end{array}$ & $\begin{array}{c}0.926^{\star * *} \\
(0.029)\end{array}$ \\
\hline PS & $\begin{array}{l}0.082^{\star *} \\
(0.034)\end{array}$ & $\begin{array}{l}0.081^{\star * *} \\
(0.029)\end{array}$ & $\begin{array}{l}0.080^{\star *} \\
(0.032)\end{array}$ & $\begin{array}{l}0.109^{* * *} \\
(0.027)\end{array}$ & $\begin{array}{c}0.165^{\star * *} \\
(0.048)\end{array}$ & $\begin{array}{c}0.073 \\
(0.053)\end{array}$ \\
\hline SECH & $\begin{array}{l}0.059^{\star} \\
(0.030)\end{array}$ & $\begin{array}{l}0.084^{\star} \\
(0.043)\end{array}$ & $\begin{array}{c}0.149^{\star * *} \\
(0.036)\end{array}$ & $\begin{array}{c}0.211^{\star * *} \\
(0.038)\end{array}$ & $\begin{array}{c}0.119^{\star * *} \\
(0.038)\end{array}$ & $\begin{array}{l}0.079^{\star *} \\
(0.035)\end{array}$ \\
\hline SS & $\begin{array}{c}0.109^{* * *} \\
(0.026)\end{array}$ & $\begin{array}{c}0.125^{\star * *} \\
(0.026)\end{array}$ & $\begin{array}{c}0.236^{\star * *} \\
(0.036)\end{array}$ & $\begin{array}{c}0.296^{* * *} \\
(0.044)\end{array}$ & $\begin{array}{c}0.298^{\star * *} \\
(0.037)\end{array}$ & $\begin{array}{c}0.168^{\star * *} \\
(0.035)\end{array}$ \\
\hline $\mathrm{EP}$ & $\begin{array}{c}0.147^{\star * *} \\
(0.051)\end{array}$ & $\begin{array}{c}0.297^{\star * *} \\
(0.075)\end{array}$ & $\begin{array}{c}0.328^{\star * *} \\
(0.085)\end{array}$ & $\begin{array}{c}0.456^{\star * *} \\
(0.098)\end{array}$ & $\begin{array}{c}0.478^{\star * *} \\
(0.102)\end{array}$ & $\begin{array}{l}0.196^{\star *} \\
(0.087)\end{array}$ \\
\hline $\mathrm{EC}$ & $\begin{array}{l}0.070^{\star * *} \\
(0.024)\end{array}$ & $\begin{array}{l}0.085^{\star *} \\
(0.036)\end{array}$ & $\begin{array}{c}0.175^{\star * *} \\
(0.032)\end{array}$ & $\begin{array}{l}0.145^{\star * \star} \\
(0.044)\end{array}$ & $\begin{array}{l}0.095^{\star * *} \\
(0.029)\end{array}$ & $\begin{array}{c}0.049 \\
(0.036)\end{array}$ \\
\hline OPEN & & & $\begin{array}{c}0.022^{* * *} \\
(0.003)\end{array}$ & $\begin{array}{c}0.042^{* * *} \\
(0.006)\end{array}$ & $\begin{array}{l}0.016^{* *} \\
(0.008)\end{array}$ & $\begin{array}{c}0.015^{\star * *} \\
(0.004)\end{array}$ \\
\hline PGDP & & & & $\begin{array}{c}0.009^{* * *} \\
(0.002)\end{array}$ & $\begin{array}{c}0.008^{\star * *} \\
(0.001)\end{array}$ & $\begin{array}{c}0.004^{* * *} \\
(0.001)\end{array}$ \\
\hline _cons & $\begin{array}{c}-0.054^{\star * *} \\
(0.017)\end{array}$ & $\begin{array}{c}-0.074^{* * *} \\
(0.025)\end{array}$ & $\begin{array}{c}-0.121^{\star * *} \\
(0.024)\end{array}$ & $\begin{array}{c}-0.156^{\star * *} \\
(0.025)\end{array}$ & $\begin{array}{c}-0.143^{\star * *} \\
(0.022)\end{array}$ & $\begin{array}{c}-0.064^{\star *} \\
(0.027)\end{array}$ \\
\hline Obs. & 300 & 300 & 300 & 300 & 300 & 300 \\
\hline $\mathrm{AR}(1)$ & 0.002 & 0.002 & 0.004 & 0.003 & & \\
\hline $\operatorname{AR}(2)$ & 0.125 & 0.111 & 0.111 & 0.318 & & \\
\hline Hansen & 1.000 & 1.000 & 1.000 & 1.000 & & \\
\hline
\end{tabular}

Note: The symbols ${ }^{* * *},{ }^{* *}$, and ${ }^{*}$ indicate that the variables are significant at the significance levels of $1 \%, 5 \%$, and $10 \%$ respectively; ar (1), ar (2), and hansen give the corresponding $\mathrm{P}$ values of the statistics; the number in brackets in the table is the $\mathrm{T}$ statistic (the robust standard error of each statistic); _cons represents a constant term. The Same below. 
of environmental protection expenditure, social security and employment expenditure. This is because there is a certain time lag in expenditures in science, education, culture, and medical care fields, and it is not possible to show a strong contribution to the economy in a short period of time. For every 1 unit increase in economic construction expenditure, the quality of economic development improves by 0.145 units, and Hypothesis 2 is proved. Although economic construction expenditure has a positive impact on the quality of economic development, its influence is low. In the early days of reform and opening up, a large amount of fiscal expenditure in China was used for economic construction, and it tended to invest in agriculture and industry, which indeed brought rapid growth in GDP. After 40 years of development, China's public infrastructure has been basically completed. Excessive economic construction expenditures have not been coordinated with other expenditures, not only has the problem of inefficient resource allocation, but also causes "crowding effect", which weakens the positive effect of economic construction expenditure on the quality of economic development. For every 1 unit increase in general public service expenditure, the quality of economic development improves by 0.109 units, and Hypothesis 1 is proved. General public service expenditure has the weakest promotion effect on the quality of economic development.

In addition, the study found that the control variables in the model also significantly affected the quality of economic development. After adding the factor of the level of opening up to the model (3), the estimation results show that the coefficient of this variable is positive at a significance level of $1 \%$, indicating that increasing the level of economic opening is conducive to improving the quality of economic development. From the regression results of model (4), after adding the per capita GDP factor, the scale factor of fiscal expenditure becomes significant, and the relationship between the level of opening up and the quality of economic development remains relatively stable, reflecting the optimization effect of new variables on the model, and the increase in per capita GDP has a positive effect on the quality of economic development.

\subsubsection{Robustness Test of Empirical Results}

First, the model (1) to model (4) gradually add control variables, and the sign and significance of the main explanation coefficients remain unchanged. Second, using Blundell \& Bond's (2000) method to test whether the estimator is valid, the results show that the coefficient estimates of the SYS-GMM (model (4)) are between the fixed effect model (model (5)) and the mixed regression model (model (6)), which confirms to a certain extent that the estimation is more effective. In summary, the robustness test from both variables and measurement methods proves that the empirical results are consistent and stable.

\subsection{Impact of Meso-Level Fiscal Expenditure Structure on High-Quality Economic Development}

Due to natural, historical, and development strategies, China's area development is imbalanced and inadequate, and the impact of area fiscal expenditure struc- 
ture on the quality of economic development will also differ. We call this difference phenomenon the regional heterogeneity effect of fiscal expenditure. Therefore, China is divided into three areas: east, central and west, and the impact of fiscal expenditure structure on the quality of economic development is studied from a meso level.

In order to overcome the problem that group regression may lose some sample information and the coefficients between groups cannot be directly compared, this paper constructs the interaction term of the area dummy variable (area) and all explanatory variables, that is, the "full interaction term" (Xie, 2013), Using the SYS-GMM regression results at the macro (national) level as the base group, examines the different impact of fiscal expenditure structure on the quality of economic development in different area. The regression results are shown in Table 5.

The estimated results shown in Table 5 all passed the AR test and Hansen test, and the lag terms coefficients of the explanatory variables QEG are also significantly positive. Therefore, the regression results in Table 5 are consistent. At the same time, by examining the joint significance of area dummy variables and various types of fiscal expenditure, it is shown that there is indeed regional heterogeneity in the impact of fiscal expenditure structure on the quality of economic development. Hypothesis 6 is proved. Based on the regression results in Table 5, we make the following analyses for the eastern, central, and western areas respectively.

The results of model (7) show that the impact of various fiscal expenditures on the quality of economic development in east is significantly positive, and the regression coefficients of various types of fiscal expenditure are greater than those in central, west and the national level, indicating that the effects of various types of fiscal expenditure in east on promoting high-quality economic development are higher than those in central, west and the national level. This is because the east has achieved the first development, and the basic conditions such as social, economic, cultural, and ecological conditions are better, which has improved the efficiency and effectiveness of fiscal expenditures. The general public service expenditure in east has the greatest impact on the quality of economic development. For every 1 unit increase in public service expenditure, the quality of economic development improves by 1.348 units. This is because in the more developed east, the management of general public service expenditure is more standardized, expenditure efficiency is higher, social affairs management is more effective, and it provides a good order environment for high-quality economic development.

The results of model (8) show that the regression coefficients of various types of fiscal expenditure in central are not much different from the national level, indicating that the economic and social development of central is a microcosm of the country.

Model (9) results show that the impact of general public service expenditures and environmental protection expenditures on the quality of economic 
Table 5. Regression results of meso-level fiscal expenditure structure and quality of economic development.

\begin{tabular}{|c|c|c|c|c|}
\hline Model & $(4)$ & (7) & (8) & (9) \\
\hline area & Nationwide & East & Central & West \\
\hline QEG (-1) & $\begin{array}{c}0.767^{* * *} \\
(0.042)\end{array}$ & $\begin{array}{c}0.707^{* * *} \\
(0.207)\end{array}$ & $\begin{array}{c}0.797^{* * *} \\
(0.103)\end{array}$ & $\begin{array}{l}0.487^{\star *} \\
(0.182)\end{array}$ \\
\hline PS & $\begin{array}{c}0.109^{* * *} \\
(0.027)\end{array}$ & $\begin{array}{c}-0.227^{* *} \\
(0.101)\end{array}$ & $\begin{array}{c}0.221^{\star * *} \\
(0.072)\end{array}$ & $\begin{array}{l}0.471^{\star *} \\
(0.194)\end{array}$ \\
\hline $\mathrm{SECH}$ & $\begin{array}{c}0.211^{* * *} \\
(0.038)\end{array}$ & $\begin{array}{c}0.564^{* * *} \\
(0.153)\end{array}$ & $\begin{array}{c}0.236 \\
(0.176)\end{array}$ & $\begin{array}{c}0.150 \\
(0.118)\end{array}$ \\
\hline SS & $\begin{array}{c}0.296^{* * *} \\
(0.044)\end{array}$ & $\begin{array}{l}0.782^{\star *} \\
(0.287)\end{array}$ & $\begin{array}{l}0.348^{\star *} \\
(0.138)\end{array}$ & $\begin{array}{c}0.386^{* * *} \\
(0.135)\end{array}$ \\
\hline $\mathrm{EC}$ & $\begin{array}{c}0.456^{* * *} \\
(0.098)\end{array}$ & $\begin{array}{c}0.150 \\
(0.439)\end{array}$ & $\begin{array}{l}0.595^{\star *} \\
(0.273)\end{array}$ & $\begin{array}{c}1.382^{\star * *} \\
(0.367)\end{array}$ \\
\hline EP & $\begin{array}{c}0.145^{\star * *} \\
(0.044)\end{array}$ & $\begin{array}{c}0.091 \\
(0.064)\end{array}$ & $\begin{array}{c}0.222^{\star} \\
(0.116)\end{array}$ & $\begin{array}{l}0.179^{\star} \\
(0.094)\end{array}$ \\
\hline OPEN & $\begin{array}{c}0.042^{* * *} \\
(0.006)\end{array}$ & $\begin{array}{l}0.227^{\star} \\
(0.112)\end{array}$ & $\begin{array}{c}0.050^{* * *} \\
(0.016)\end{array}$ & $\begin{array}{c}0.058^{* * *} \\
(0.015)\end{array}$ \\
\hline EXP & $\begin{array}{c}0.099^{* * *} \\
(0.025)\end{array}$ & $\begin{array}{l}0.344^{\star *} \\
(0.153)\end{array}$ & $\begin{array}{l}0.172^{\star *} \\
(0.076)\end{array}$ & $\begin{array}{l}0.418^{\star} \\
(0.207)\end{array}$ \\
\hline PGDP & $\begin{array}{c}0.009^{\star * *} \\
(0.002)\end{array}$ & $\begin{array}{l}-0.004 \\
(0.018)\end{array}$ & $\begin{array}{l}0.009^{*} \\
(0.004)\end{array}$ & $\begin{array}{c}0.019^{\star * *} \\
(0.006)\end{array}$ \\
\hline area & & $\begin{array}{c}-0.271^{\star} \\
(0.137)\end{array}$ & $\begin{array}{l}-0.123 \\
(0.318)\end{array}$ & $\begin{array}{c}0.128 \\
(0.136)\end{array}$ \\
\hline $\operatorname{area}^{\star} \mathrm{QEG}(-1)$ & & $\begin{array}{l}-0.309 \\
(0.323)\end{array}$ & $\begin{array}{l}-0.036 \\
(0.446)\end{array}$ & $\begin{array}{l}-0.096 \\
(0.263)\end{array}$ \\
\hline $\operatorname{area}^{\star}$ PS & & $\begin{array}{c}1.575^{* * *} \\
(0.486)\end{array}$ & $\begin{array}{l}-0.542 \\
(0.372)\end{array}$ & $\begin{array}{c}-0.853^{* *} \\
(0.315)\end{array}$ \\
\hline $\operatorname{area}^{\star} \mathrm{SECH}$ & & $\begin{array}{l}-0.244 \\
(0.206)\end{array}$ & $\begin{array}{c}0.486 \\
(0.465)\end{array}$ & $\begin{array}{c}0.441 \\
(0.262)\end{array}$ \\
\hline $\operatorname{area}^{*} S S$ & & $\begin{array}{l}-0.744 \\
(0.539)\end{array}$ & $\begin{array}{c}0.255 \\
(0.426)\end{array}$ & $\begin{array}{l}-0.036 \\
(0.249)\end{array}$ \\
\hline $\operatorname{area}^{\star} \mathrm{EC}$ & & $\begin{array}{c}2.504^{* * *} \\
(0.902)\end{array}$ & $\begin{array}{c}1.784 \\
(1.599)\end{array}$ & $\begin{array}{c}-2.203^{* *} \\
(1.042)\end{array}$ \\
\hline $\operatorname{area}^{\star} \mathrm{EP}$ & & $\begin{array}{l}0.368^{*} \\
(0.186)\end{array}$ & $\begin{array}{l}-0.018 \\
(0.457)\end{array}$ & $\begin{array}{c}0.033 \\
(0.152)\end{array}$ \\
\hline $\operatorname{area}^{*} \mathrm{EXP}$ & & $\begin{array}{l}0.583^{* *} \\
(0.274)\end{array}$ & $\begin{array}{c}0.201 \\
(0.368)\end{array}$ & $\begin{array}{l}-0.279 \\
(0.238)\end{array}$ \\
\hline area $^{\star P G D P}$ & & $\begin{array}{c}0.026 \\
(0.021)\end{array}$ & $\begin{array}{l}-0.031 \\
(0.032)\end{array}$ & $\begin{array}{l}-0.011 \\
(0.016)\end{array}$ \\
\hline $\operatorname{area}^{\star} \mathrm{OPEN}$ & & $\begin{array}{l}-0.114 \\
(0.101)\end{array}$ & $\begin{array}{c}0.278 \\
(0.367)\end{array}$ & $\begin{array}{c}0.038 \\
(0.083)\end{array}$ \\
\hline _cons & $\begin{array}{c}-0.156^{* * *} \\
(0.025)\end{array}$ & $\begin{array}{c}-0.288^{* *} \\
(0.107)\end{array}$ & $\begin{array}{c}-0.234^{* *} \\
(0.098)\end{array}$ & $\begin{array}{c}-0.253^{* * *} \\
(0.083)\end{array}$ \\
\hline Obs. & 300 & 300 & 300 & 300 \\
\hline $\operatorname{AR}(1)$ & 0.003 & 0.004 & 0.014 & 0.069 \\
\hline $\operatorname{AR}(2)$ & 0.318 & 0.611 & 0.302 & 0.391 \\
\hline Hansen & 1.000 & 1.000 & 1.000 & 1.000 \\
\hline
\end{tabular}

Note: Same as Table 4.

development in west are significantly negative. In west where is relatively backward, general public service expenditures need to be regulated and expenditure benefits need to be improved. There are some serious environmental quality problems such as low forest coverage, water scarcity, and desertification in west. 
As the ecological barrier of china, the government should take environmental protection as an important part of Western Development Strategy. The expenditure of science, education, culture and health on the quality of economic development is not significant, which indicates that there is a very obvious lagging effect of expenditure on science, education, culture and health in west. The impact of social security and employment expenditure and economic construction expenditure on the quality of economic development is significantly positive, and slightly higher than the national level.

\section{Research Conclusions and Policy Recommendations}

\subsection{Research Conclusion}

This paper quantitatively measures the quality of economic development in 30 provinces in China from 2007 to 2017 by constructing a quality of economic development comprehensive evaluation index system. Based on this, a systematic GMM empirical analysis model is used to examine the effect of fiscal expenditure structure on the quality of economic development. The research results show that, China's fiscal expenditure structure has different effects on high-quality economic development, which is reflected in differences in the effects of different expenditure items and regional heterogeneity. 1) At the macro level, all types of fiscal expenditures have a positive effect on the quality of economic development, and the functions are ranked from large to small in terms of environmental protection expenditures, social security and employment expenditures, expenditure for science, education, culture and health, economic construction expenditure, and general public service expenditure. 2) At the meso level, there is a clear regional heterogeneity in the impact of various fiscal expenditures on the quality of economic development. The promotion effect of science, education, culture and health expenditures on the quality of economic development is significantly higher in east than in central and west; increasing social security and employment expenditure has the most significant improvement in the quality of economic development in east, followed by west, and finally central; although economic construction expenditure has a positive effect on the improvement of the quality of economic development, the impact is not as effective as science, education, culture and health expenditures and social security and employment expenditures; general public service expenditure in east has an even greater effect on the quality of economic development than social security and employment expenditures and science, education, culture, and health expenditures, which has shown a weak positive promotion effect in central, while the effect of general public service expenditure in west has not been fully exerted; the positive impact of environmental protection expenditure on the quality of economic development is most effective in east and central, while it is significantly negative in west.

\subsection{Policy Recommendations}

During the period of China's economic transition, we must grasp the spirit of 
the 19th National Congress to focus on ensuring high-quality economic development, rationally arrange fiscal expenditures, optimize the structure of fiscal expenditures, determine the focus of fiscal expenditures, and give better play to the functions of fiscal expenditures to empower high-quality economic development.

\subsubsection{Optimize the Structure of Fiscal Expenditures and Empower High-Quality Economic Development}

When arranging fiscal expenditure, first the government should insist on economic construction as the center. As the basic national conditions remain unchanged in the primary stage, uncertainties in world economic development have increased. In order to stabilize the development of the Chinese economy, economic construction expenditures should focus on supporting high-tech fields, improve scientific and technological support capabilities, and continuously bring new-generation information technology, new materials, and new energy sources, etc. these high-tech achievements to comprehensively apply to manufacturing, develop a real economy centered on advanced manufacturing, transformate and upgrade traditional industries, cultivate and develop emerging industries, promote the transformation and upgrading of industrial structures, and promote economic transformation and development. Second, continuously increase spending in the fields of science, education, culture, health, social security and employment, and environmental protection. In-depth implementing the innovation-driven development strategy, developing more equitable and quality education, focusing on improving the quality of the population and human capital, and shaping China's new advantages development; safeguarding and improving people's livelihood during development, and continuing to fight the battle against precision poverty alleviation and pollution prevention. Third, with the transformation of government functions as the core, continuing to reduce general public service expenditures by continuing to simplify administration and decentralization, promote institutional reform, and improve institutional mechanisms, promoting the construction of a rule of law government and governance innovation, and strictly controlling the expenditure of the "three public" funds, eliminating low effective and ineffective expenditure, improving administrative efficiency. Finally, the quality of economic development was incorporated into the assessment system to reduce performance competition of the "GDP-only theory".

\subsubsection{Implement a Differentiated Fiscal Expenditure Policy to Promote Coordinated Development among Regions}

The economic and social development of each area is quite different. It is necessary to formulate a reasonable fiscal expenditure policy according to local conditions, strive to solve the problem of imbalanced and inadequate regional development, and optimize the pattern of coordinated regional development. For east with the highest quality of economic development, the government should shift the focus of expenditure to the people's livelihood, develop science, education, 
culture, health, promote the transformation of economic development mode, improve social security and income distribution systems, adhere to the construction of ecological civilization, and meet the needs of the people for a better life; and economic construction expenditure should be more applied to optimize the economic structure, maintain the coordination and stability of development; general public service expenditure should be conducive to the government to provide quality services and perform management functions, to provide a fair and orderly socio-economic development environment. For central and west where the quality of economic development is medium and low, there are still shortcomings in the areas of public services, people's livelihood, ecological civilization, infrastructure, and innovation, etc. The government should strictly control and reduce the general public service expenditure when arranging fiscal expenditures, improve the efficiency of fiscal expenditures, free up more resources, increase expenditure on science, education, culture, health, social security and employment, continue to promote development-oriented poverty reduction efforts, strengthen investment in public goods and services, and promote equalization of public services; resolutely implementing the policy guidance of protecting the ecological environment is protecting productivity, and improving the ecological environment is developing productivity; at the same time, paying attention to infrastructure construction and increasing support for major engineering projects such as transportation, communications, energy, and people's livelihood. Make up the shortcomings and provide strong support for the high-quality development of the economy in central and west.

\section{Conflicts of Interest}

The author declares no conflicts of interest regarding the publication of this paper.

\section{References}

Aschauer, D A. (1989). Is Public Expenditure Productive? Staff Memoranda, 23, 177-200. https://doi.org/10.1016/0304-3932(89)90047-0

Barro, R. J. (1990). Government Spending in a Simple Model of Endogeneous Growth. Journal of Political Economy, 98, 103-126. https://doi.org/10.1086/261726

Blundell, R., \& Bond, S. (2000). GMM Estimation with Persistent Panel Data: An Application to Production Functions. Econometric Reviews, 19, 321-340. https://doi.org/10.1080/07474930008800475

Chao, X. J. (2009). Measurement of the Quality of China's Economic Growth. Research on Quantitative Economic Technology \& Economy, 26, 75-86.

Devarajan, S., Swaroop, V., \& Zou, H. (1993). What Do Governments Buy? The Composition of, Public Spending and Economic Performance. Policy Research Working Paper.

Guo, L. (2018). Empirical Research on the Impact of Fiscal Decentralization on China's Regional Economy: Based on the Two-Dimensional Perspective of the Quality and Speed of Economic Growth. Technology Economy and Management Research, No. 5, 95-99. 
Guo, Q. W., Lu, B. Y., \& Zhang, D. Y. (2003). Fiscal Expenditure Structure and Economic Growth. Economic Theory and Economic Management, 22, 5-12.

Li, N., Li, X. T., Wei, Y., \& Sun, Y. (2018). Socioeconomic Effects of Fiscal Expenditure: Analysis and Optimization Based on Panel Random Forest. Management Review, 30, 258-269.

Lin, C., \& Sun, Y. (2017). Regional Differences in the Quality of Economic Growth in the Background of Fiscal Decentralization: A Test Based on Systematic GMM and Threshold Effects. Finance and Economics Journal, No. 12, 35-44.

Liu, C. K., \& Wang, C. C. (2008). An Empirical Analysis of Fiscal Expenditure Structure and Social Equity. Finance Research, No. 2, 15-18.

Ren, B. P. (2018). Measurement and Analysis of the High-quality Development of China's Provincial Economy. Economic Issues, No. 4, 1-6.

Ren, B. P., \& Li, Y. M. (2018). Construction of China's High Quality Development Evaluation System in the New Era and Its Transformation Path. Journal of Shaanxi Normal University (Philosophy and Social Science Edition), 47, 105-113.

Sun, J. W. (2018). From High-Speed Economic Growth to High-Quality, Balanced Regional Development. Regional Economic Review, No. 1, 1-4.

Sun, W. X., \& Zhang, Z. C. (2004). The Impact of Fiscal Expenditure Structure on Economic Growth and Social Equity. Journal of Shanghai University of Finance and Economics, 6, 3-9.

Wang, C. Y. (2009). An Empirical Analysis of the Relationship between the Government's Fiscal Expenditure Structure and Economic Growth. Finance and Economics Research, No. 6, 121-131.

Wei, J., \& Ren, B. P. (2012). The Measurement and Ranking of Quality Index of Economic Growth in Different Regions of China. Economic Update, No. 4, 27-33.

Wei, M., \& Li, S. H. (2018). Construction and Measurement of the Quality Evaluation System of China's Economic Growth under the New Normal. Economist, No. 4, 19-26.

Wei, X. X., \& Li, F. (2012). Empirical Study on the Impact of Fiscal Expenditure Structure Benefits on National Happiness Index. Economic Issues, No. 1, 117-120.

Xiao, H. Y., \& Li, L. S. (1998). Empirical Analysis of the Quality of China's Economic Growth. Statistical Research, No. 4, 8-14.

Xie, Y. (2013). Regression Analysis. Beijing: Social Science Literature Press.

Yan, C. L. (2017). Delayed Retirement, Adjustment of Fiscal Expenditure Structure and Pension Replacement Ratio. Financial Research, No. 9, 51-66.

Zeng, J. H., \& Zhao, F. (2005). Research on Optimal Fiscal Expenditure Structure to Promote China's Economic Growth. Journal of Zhongnan University of Economics and Law, No. 4, 77-81.

Zhan, X. Y., \& Wang, S. (2017). Study on the Mass Effect of Economic Growth in Fiscal Expenditure Structure: Based on the Perspective of "Five Development Ideas". Contemporary Finance and Economics, No. 4, 25-37.

Zhao, Y. C., Zhang, C. H., \& Liu, H. Y. (2006). Comprehensive Evaluation of the Quality of China's Economic Growth Since the Transition. Journal of Social Science of Jilin University, No. 3, 27-35.

Zhong, X. Y. (2001). Transformation of Growth Mode and Improvement of Growth Quality. Beijing: Economic Management Press. 